\title{
MODEL PRIORITAS PENANGANAN DAERAH RESAPAN AIR (RECHARGE AREA) DI WILAYAH SUNGAI BENGAWAN SOLO MENGGUNAKAN MULTI CRITERIA DECISION MAKING DAN GEOGRAPHIC INFORMATION SYSTEM
}

\author{
Edy Sriyono $^{1}$ \\ ${ }^{1}$ Jurusan Teknik Sipil,Universitas Janabadra, Yogyakarta 55231 \\ E-mail :edysriyono@janabadra.ac.id
}

\begin{abstract}
ABSTRAK
Penentuan daerah resapan air (DRA) dipengaruhi oleh 14 parameter. Ke 14 parameter ini oleh para ahli ditentukan parameter yang dominan. Parameter utama adalah kondisi geologi, jenis lapis tanah permukaan, curah hujan dan kondisi kelerengan lahan. Masing-masing parameter memiliki bobot pengaruh tergantung kondisi wilayahnya. Sesudah DRA dapat ditentukan maka dapat pula ditentukan prioritas penanganan DRA tersebut. Metode yang digunakan terdiri dari proses pengembangan model MCDM dan proses overlay layer SIG. Analisis pengambilan keputusan yang paling tepat yaitu: Analytic Hierarchy Process (AHP) serta Analytic Network Process (ANP). Overlay antar parameter dilakukan dengan Sistem Informasi Geografis dengan menggunakan bobot untuk mendapatkan skor akhir. Hasil penelitian menunjukkan bahwa terdapat 532.475,01 Ha DRA di Wilayah Sungai Bengawan Solo, terdiri dari 387.069,29 Ha Prioritas II dan 145.405,72 Ha Prioritas I. Luas total DRA sekitar 29,7\% dari luar wilayah sungai. Dari hasil penentuan DRA, dapat disimpulkan bahwa ciri-ciri utama: Air tanah mengalir vertikal ke bawah, Air merembes masuk mencapai muka air tanah, Singkapan batuannya adalah lolos air serta tak jenuh air, Umumnya berupa perbukitan, Umur air tanah relatif muda, Badan serta puncak kerucut yang berasal dari gunung api, Pada karst memiliki retakan serta lubang pelarutan. Terdapat pula beberapa kawasan permukiman yang berada di DRA.
\end{abstract}

Kata Kunci: AHP, ANP, Recharge area, Geographic Information System, Parameter pengaruh

\section{ABSTRACT}

Determination of recharge area (RA) is influenced by 14 parameters. These 14 parameters are determined by the experts as the dominant parameter. The main parameters are geological conditions, type of surface soil layer, rainfall, and land slope conditions. Each parameter has a weight of influence depending on the condition of the region. After the RA can be determined, the priority for handling the RA can also be determined. The method used consists of the MCDM model development process and the GIS layer overlay process. The most appropriate decision-making analysis are: Analytic Hierarchy Process (AHP) and Analytic Network Process (ANP). Overlay between parameters is done by Geographic Information System by using weights to get the final score. The results showed that there were 532,475.01 Ha of RA in the Bengawan Solo River Basin, consisting of 387,069.29 Ha Priority II and 145,405.72 Ha Priority I. The total area of RA was about $29.7 \%$ from outside the river area. From the results of the RA determination, it can be concluded that the main characteristics are: Having a vertical downward flow of groundwater, Water percolating to the ground water table, Outcrop areas of rock that escape unsaturated water, Hilly areas, relatively young groundwater age, Body area and the top of the volcanic cone, karst area that has cracks and dissolution holes. There are also several residential areas in RA.

Keywords: AHP, ANP, Recharge area, Geographic Information System, Influence parameters

\section{PENDAHULUAN}

Daerah Resapan Air (DRA)/Recharge Area adalah area yang mana air yang masuk berasal dari permukaan tanah masuk ke dalam daerah jenuh air kemudian menjadi aliran air tanah yang mengalir mencari daerah yang lebih rendah. Area ini merupakan area yang sangat penting bagi keberlangsungan siklus hidrologi. Keberadaan air sangat dipengaruhi adanya tata guna lahan yang berubah di area resapan air. Berubahnya tata guna lahan akan berpengaruh terhadap tersedianya serta terpakainya air. Contohnya pada saat suatu area hutan di daerah resapan air berubah jadi permukiman penduduk maka pada satu sisi keterpakaian akan air menjadi naik dikarenakan digunakan oleh masyarakat di permukiman itu sedangkan pada sisi lain tersedianya air menjadi menurun dikarenakan area resapan airnya menurun.

Saat area di daerah resapan air berubah maka akan meningkatkan debit yang mengalir di atas permukaan lahan. Hal ini akan mengakibatkan di daerah hilir memperoleh debit lebih besar serta dapat menjadi genangan/banjir. Perubahan area juga menyebabkan terdapatnya erosi lahan. Sewaktu area tata guna lahan berubah dapat meningkatkan aliran air di atas permukaan 
serta air tak bisa tertampung dalam DAS. Ketika ada hujan seluruh air akan mengalir ke sungai dan bisa menimbulkan kekurangan air di musim kering. Saat debit air naik, aliran air di sungai juga meningkat dengan sedimen yang dibawanya besar pula yang pada akhirnya kapasitas sungai menjadi menurun serta di outlet aliran air di sungai atau di muara bisa menimbulkan pendangkalan. [1]. Selain itu, DRA juga merupakan penyumbang kelestarian air tanah (ground water) [2]; [3]; [4].

Beberapa penelitian tentang pentingnya peran DRA [5], [6] menjelaskan bahwa DRA sangat dibutuhkan dalam manajemen air tanah dan kualitas air, sehingga perlu penentuan DRA. Penentuan DRA ini penting dipakai dalam perencanaan pengelolaan sumber daya air. Beberapa penelitian tentang penentuan DRA yang potensial telah dilakukan oleh beberapa peneliti, seperti [7] dengan menggunakan data raster dan di overlay dengan jenis variabel dan bobot yaitu slope dengan bobot 20\%, geomorphology dengan bobot $25 \%$, soil dengan bobot $20 \%$, land use/land cover dengan bobot $25 \%$, drainage density dengan bobot 5\%, dan lineament density dengan bobot 5\%. Selanjutnya di tahun yang sama [8], memakai metode Analytical Hierarchy Process (AHP) dan GIS untuk mengidentifikasi DRA dengan mempertimbangkan 11 variabel. [9] menggunakan 8 variabel (SLUGGER-DQL-Tanah, Tata Guna Lahan, Geomorfologi, Geologi, Kerapatan sumur, Kualitas Air, Kedalaman Air Tanah) untuk menentukan DRA dengan bantuan GIS dengan data bermodel raster dan melakukan pembobotan pada masing-masing variabel.

Hasil review terhadap penelitian terdahulu menunjukkan bahwa untuk menentukan daerah resapan air (DRA) diperlukan beberapa parameter. Tiap peneliti memiliki asumsi masing-masing untuk menetapkan parameter tersebut. Dalam tataran kelembagaan, belum ada standar baku untuk penentuan DRA dan semua diserahkan kepada masing-masing pemerintah daerah. Sehingga perlu ditetapkan kriteria baku yang menjadi acuan pemerintah daerah dalam menetapkan zonasi kawasan-kawasan potensial guna meresapkan air ke dalam tanah. Selain fungsi kawasan resapan air sebagai pengisi tambahan cadangan air tanah juga berfungsi guna mengurangi potensi kemungkinan terjadinya banjir. Oleh karena itu, diperlukan penelitian tentang variabel penentu DRA beserta bobot pengaruhnya.

Namun demikian, pengaruh bobot tiap-tiap parameter belum sempat dinilai secara mendalam. Kasus ini bisa dipecahkan dengan memakai pendekatan Multi-Criteria Decision-Making (MCDM). MCDM adalah sub-disiplin penelitian pembedahan dengan cara eksplisit mengevaluasi beberapa kriteria yang berlawanan ketika mengambil sebuah keputusan. MCDM dinyatakan selaku sesuatu tata cara dalam mengambil keputusan guna memperoleh alternatif paling baik dari beberapa alternatif bersumber pada sebagian kriteria yang ditentukan. Sebagian yang tercantum dalam model MCDM yang terkenal dan banyak dipakai dikala ini terdiri dari: Scoring Model, Analytic Herarchy Process (AHP), Analytic Network Process (ANP), Utility Model, Out Ranking Method, Technique for Others Reference by Similarity to Sempurna Solution (TOPSIS), serta yang lain.

Dalam kasus penentuan DRA ini akan menerapkan MCDM (dipilih metode AHP dan ANP) untuk menentukan bobot pengaruh masing-masing variabel untuk penentuan DRA. Hasil bobot variabel selanjutnya akan digunakan sebagai masukan data dalam Sistem Informasi Geografis untuk penentuan DRA.

\section{TINJAUAN PUSTAKA}

\subsection{Variabel Penentu DRA}

Variabel untuk penentuan daerah resapan air dalam penelitian ini, dikaji dari beberapa penelitian terdahulu [8]; [7]; [10] dan beberapa peraturan yang pernah ada.

Variabel utama untuk penentuan DRA adalah kondisi geologi, jenis lapis tanah permukaan, curah hujan dan kondisi kelerengan lahan [11]. Masing-masing variabel memiliki bobot pengaruh yang berbeda tergantung kondisi wilayahnya dengan faktor dominan adalah kondisi geologi. Dalam kasus WS Bengawan Solo, bobot masing-masing variabel adalah: geologi $(40 \%)$, jenis lapis tanah permukaan $(30 \%)$, curah hujan $(20 \%)$, dan kelerengan $(10 \%)$.

Beberapa parameter yang berhasil dihimpun selanjutnya diperlihatkan pada Tabel 1. Kemudian diimplementasikan dengan data dari Daerah Aliran Sungai (DAS) Bengawan Solo sebagai area sampel penelitian.

Tabel 1. Parameter untuk menentukan daerah resapan dari penelitian sebelumnya.

\begin{tabular}{|c|c|c|c|c|c|c|c|c|}
\hline No. & Parameter & $\begin{array}{l}\text { TCEQ } \\
\text { Regulatory } \\
\text { Guidance, } \\
2005\end{array}$ & $\begin{array}{l}\text { Hammouri } \\
\text { et al., } \\
2014\end{array}$ & $\begin{array}{l}\text { Kaliraj, } \\
\text { Chandrasekar, } \\
\text { and Magesh, } \\
2014\end{array}$ & [7] & [10] & $\begin{array}{l}\text { Permen } \\
\text { PUPR } \\
\text { 10/PRT/ } \\
\text { M/2015, } \\
2015\end{array}$ & $\begin{array}{l}\text { Kresnanto } \\
\& \\
\text { Sriyono, } \\
2019\end{array}$ \\
\hline 1 & $\begin{array}{l}\text { Kerapatan } \\
\text { Drainase } \\
\left(\mathrm{km} / \mathrm{km}^{2}\right) \\
\end{array}$ & & & $\checkmark$ & $\sqrt{ }$ & $\sqrt{ }$ & & \\
\hline 2 & Tata guna/ & $\checkmark$ & $\checkmark$ & $\checkmark$ & $\sqrt{ }$ & $\sqrt{ }$ & $\checkmark$ & $\checkmark(30 \%)$ \\
\hline
\end{tabular}




\begin{tabular}{|c|c|c|c|c|c|c|c|c|}
\hline No. & Parameter & $\begin{array}{l}\text { TCEQ } \\
\text { Regulatory } \\
\text { Guidance, } \\
2005\end{array}$ & $\begin{array}{l}\text { Hammouri } \\
\text { et al., } \\
2014\end{array}$ & $\begin{array}{l}\text { Kaliraj, } \\
\text { Chandrasekar, } \\
\text { and Magesh, } \\
2014\end{array}$ & [7] & [10] & $\begin{array}{l}\text { Permen } \\
\text { PUPR } \\
\text { 10/PRT/ } \\
\text { M/2015, } \\
2015\end{array}$ & $\begin{array}{l}\text { Kresnanto } \\
\& \\
\text { Sriyono, } \\
2019\end{array}$ \\
\hline & Tutupan lahan & & & & & & & \\
\hline 3 & $\begin{array}{l}\text { Kerapatan } \\
\text { kelurusan } \\
\left(\mathrm{km} / \mathrm{km}^{2}\right) \\
\end{array}$ & & & $\checkmark$ & $\sqrt{ }$ & $\sqrt{ }$ & & \\
\hline 4 & Geomorfologi & $\checkmark$ & $\checkmark$ & $\checkmark$ & $\checkmark$ & $\checkmark$ & & \\
\hline 5 & $\begin{array}{l}\text { Kemiringan } \\
\text { (derajat) }\end{array}$ & & & $\checkmark$ & $\checkmark$ & & $\checkmark$ & $\checkmark(10 \%)$ \\
\hline 6 & $\begin{array}{l}\text { Permeabilitas } \\
\operatorname{tanah}(\mathrm{m} / \text { hari } \\
(\text { vertikal }))\end{array}$ & $\checkmark$ & $\checkmark$ & $\checkmark$ & $\checkmark$ & & $\checkmark$ & \\
\hline 7 & $\begin{array}{l}\text { Tekstur tanah } \\
\text { (ukuran butir } \\
\text { dalam mm) }\end{array}$ & & & $\checkmark$ & & & & \\
\hline 8 & $\begin{array}{l}\text { Kedalaman } \\
\text { tanah } \\
\text { (mvertikal) }\end{array}$ & & & $\checkmark$ & & & & \\
\hline 9 & $\begin{array}{l}\text { Curah hujan } \\
(\mathrm{mm})\end{array}$ & & & $\checkmark$ & & & $\checkmark$ & $\checkmark(20 \%)$ \\
\hline 10 & Geologi & & $\checkmark$ & $\checkmark$ & & & & $\checkmark(40 \%)$ \\
\hline 11 & $\begin{array}{l}\text { Transmisivitas } \\
\text { aquifer }\left(\mathrm{m}^{2} / \mathrm{hr}\right)\end{array}$ & & & $\checkmark$ & & & & \\
\hline 12 & $\begin{array}{l}\text { Kerapatan } \\
\text { sumur }\end{array}$ & & $\checkmark$ & & & & & \\
\hline 13 & Kualitas air & & $\checkmark$ & & & & & \\
\hline 14 & $\begin{array}{l}\text { Kedalaman air } \\
\text { tanah }\end{array}$ & & $\checkmark$ & & & & & \\
\hline
\end{tabular}

Berdasarkan studi literatur dapat diketahui bahwa ada 14 variabel yang dapat digunakan untuk menentukan daerah resapan air. Ke 14 variabel ini disebut dengan daftar panjang variabel (longlist of variable), dan dari 14 variabel ini selanjutnya akan didiskusikan dengan para ahli (expert) untuk menentukan variabel yang dominan yang akan dipakai beserta bobot pengaruhnya.

\subsection{Multi Criteria Decision Making (MCDM)}

MCDM ataupun Multiple-Criteria-Decision-Analysis (MCDA) merupakan sub-disiplin riset pembedahan dengan cara eksplisit yang dapat mengevaluasi sebagian kriteria yang berlawanan dalam proses mengambil keputusan. Dalam [12], MCDM dinyatakan selaku sesuatu tata cara mengambil keputusan buat memutuskan alternatif paling baik terhadap beberapa alternatif bersumber pada sebagian kriteria yang ditentukan. Dalam [13], kelebihan tata cara ini bisa memperkirakan akibat secara finansial ataupun non finansial (dapat diukur serta tidak dapat diukur). Menurut [14], sebagian model MCDM yang terkenal dan banyak dipakai dikala ini adalah: Scoring Model, Analytic Heiarchy Process (AHP), Analytic Network Process (ANP), Utility Model, Out Ranking Method, Technique for Others Reference by Similarity to Ideal Solution (TOPSIS), serta yang lain.

Pada penelitian ini akan dikaji dua cara multi kriteria yaitu AHP dan model yang rencana akan digunakan (ANP). AHP dan ANP dipilih untuk dijadikan titik berat penelitian dengan alasan mempunyai berbagai kelebihan yang akan dijelaskan dalam bab berikutnya. Cara ini digunakan karena telah banyak dikembangkan oleh beberapa pakar di berbagai bidang, seperti dikemukakan oleh beberapa reviewer [15]; [16];[17]; [18]; [19]; [20]. Selain itu, cara AHP serta ANP merupakan cara yang dalam pengembangan sama, metode ANP adalah pengembangan dari AHP [21]; [22], sehingga nanti akan bisa dilihat efektivitas kedua metode tersebut.

\subsection{Analytic Hierarchy Process (AHP)}

Analytic hierarchy process (AHP) merupakan suatu cara yang bisa dipakai dalam sistem pengambilan keputusan. AHP ditemukan oleh Thomas L. Saaty sekitar tahun 70-an. Melalui metode ini permasalahan multi kriteria rumit dapat diurai dalam jenjang hierarki. Hierarki merepresentasikan suatu masalah rumit dari suatu jenjang multi level dengan level kesatu yaitu tujuan, level berikutnya faktor, kriteria, sub kriteria, dan selanjutnya hingga level paling bawah dari suatu alternatif [23]; [24]. 
Dalam proses mengambil keputusan tujuannya adalah menetapkan alternatif terbaik. Sebagai contoh membuat struktur persoalan, menentukan berbagai alternatif, menetapkan nilai peluang pada parameter aleatori, penetapan nilai, membuat syarat preferensi mengenai waktu, serta spesifikasi terhadap risiko. Meskipun alternatifnya melebar dapat ditetapkan secara terperinci pencarian nilai peluang, keterbatasan yang menjadi dasar perbandingan yang merupakan kriteria tunggal.

Melalui hierarki, masalah yang rumit bisa diurai menjadi grup-grupnya untuk selanjutnya diatur ke dalam suatu hierarki yang menjadikan permasalahan menjadi berstruktur serta sistematik. Cara AHP ini dapat dipakai walaupun tidak ada hubungan antara beberapa kriterianya.

\subsection{Analytic Network Process (ANP)}

Analytic Network Process (ANP) ialah suatu cara yang dipakai untuk mengambil keputusan. Tata cara ini ialah pertumbuhan tata cara Analytic Hierarchy Process (AHP). Keuntungan dari ANP ialah merupakan tata cara dalam mengambil keputusan dengan proses simpel sehingga bisa digunakan dalam permasalahan lingkungan. Kesederhanaan dari tata cara ANP menjadikan ANP selaku tata cara yang lebih universal serta lebih gampang diaplikasikan buat riset kualitatif yang bermacammacam, semacam pengambilan keputusan, peramalan, penilaian, pemetaan serta lain sebagainya [25].

ANP juga merupakan alternatif untuk penyelesaian masalah dengan kriteria yang banyak serta berkaitan atau mempengaruhi saat mengambil keputusan. Cara yang memakai pendekatan seperti jaringan ini, dengan tidak selalu membuat level sebagaimana hierarki yang dipakai pada AHP. Namun karena cara ini tergolong baru, maka masih sedikit yang menggunakannya sebagai metode pemecahan masalah.

ANP juga merupakan cara pengukuran relatif, umumnya dipakai guna merendahkan perbandingan prioritas komposit terhadap skala perbandingan individu dengan menggambarkan pengukuran relatif akibat saling pengaruh elemen-elemen yang berkaitan terhadap kriteria kontrol [26]. ANP adalah suatu cara matematis sehingga membuat seseorang secara sistematis melaksanakan dependence serta feedback sehingga bisa mengambil serta mengawinkan faktor tangible dengan faktor intangible [27].

Ada tujuh pilar utama pada konsep AHP: (1) skala perbandingan, (2) rasio bergandengan, (3) kondisi-kondisi sensitif terhadap vektor eigen, (4) homogenitas serta klasterisasi, (5) sintesa, (6) menetapkan serta membalik urutan, serta (7) mempertimbangkan grup. Tujuh pilar AHP ini mempunyai fungsi menjadikan titik awal ANP. ANP memberi gambaran umum dalam membuat keputusan meskipun tanpa merumuskan asumsi terhadap keleluasaan tingkat-tingkat unsur yang berada lebih tinggi [26].

Dalam pemberian bobot ANP diperlukan model untuk dapat menggambarkan keterkaitan antara kriteria dengan sub kriterianya. Terdapat dua kontrol harus dipertimbangkan untuk membuat model sistem untuk mengetahui pembobotannya. Kontrol kesatu yaitu kontrol hierarki guna menggambarkan terkaitnya kriteria serta sub kriteria. Dengan kontrol ini tak diperlukan adanya jenjang hierarki sebagaimana cara AHP. Kontrol kedua yaitu kontrol terhadap saling terkaitnya antar kriteria atau kluster [24].

\subsection{Sistem Informasi Geografis (SIG)}

SIG atau Sistem Informasi Geografis (SIG) yaitu sistem informasi khusus pengelolaan data yang mempunyai informasi spasial (dengan referensi ruang). Dengan kata lain SIG, merupakan sistem komputerisasi dengan keutamaan membuat, melakukan penyimpanan, melakukan pengelolaan serta membuat tampilan informasi berdasar referensi kondisi geografi, seperti identifikasi data berdasar lokasinya, dengan bentuk database. SIG ini selanjutnya akan dipakai untuk membantu mengidentifikasi DRA dengan cara mengoverlay (analisis spasial) masing-masing variabel yang telah ditentukan bobot pengaruhnya dengan MCDM.

\section{METODE PENELITIAN}

\subsection{Sistem Informasi Geografis (SIG)}

Metode yang dipilih untuk penelitian ini adalah analisis pengambilan keputusan yang paling tepat di antara beberapa metode dalam analisis Multiple Criteria Decision Making adalah: Analytic Hierarchy Process (AHP) serta Analytic Network Process (ANP). Multi Criteria Decision Making (MCDM) adalah suatu metode paling sering dipakai untuk proses dalam mengambil keputusan. MCDM mempunyai tujuan untuk mendapatkan alternatif yang paling baik terhadap banyak alternatif eksklusif paling menguntungkan berdasar performa umum di berbagai kriteria yang sudah ditetapkan oleh orang yang mengambil keputusan.

Adapun urutan pengembangan model MCDM yaitu:

1. Mempersiapkan mengenai kajian literatur,

2. Menginventarisasi dan memilih kriteria serta sub kriteria dalam menentukan DRA,

3. Mengumpulkan data,

4. Membuat Analytic Hierarchy Process (AHP)Model serta Analytic Network Process (ANP) Model, 
5. Analisis perbandingan metode AHP serta metode ANP,

6. Validasi dan uji model dengan sampel WS Bengawan Solo,

7. Membuat kesimpulan serta memberi saran.

Selanjutnya, urutan-urutan penelitian ini dapat dilihat dengan lebih jelas dalam Error! Reference source not found.

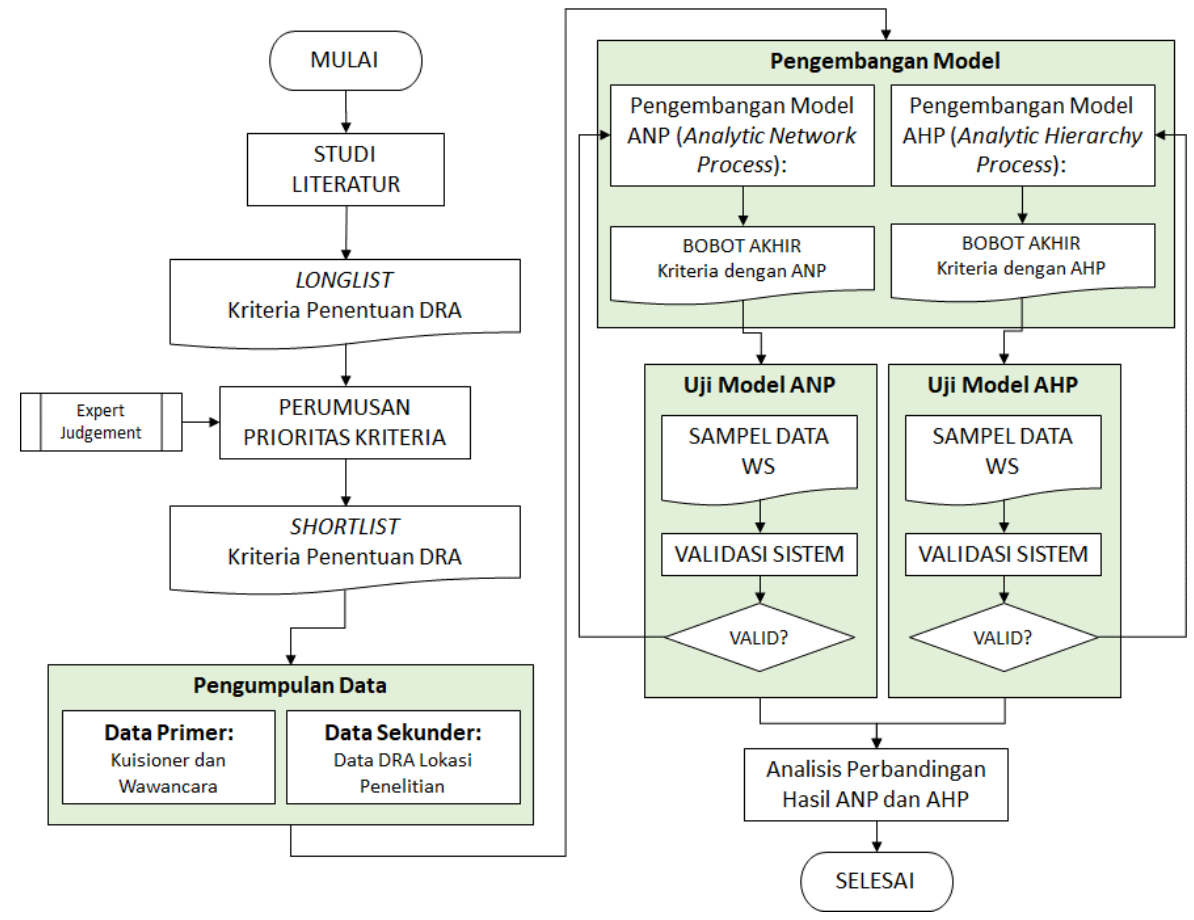

Gambar 1. Flowchart Metode Penelitian

\subsection{Proses Overlay Layer SIG}

Overlay antar variabel akan dilakukan dengan bantuan Sistem Informasi Geografis sesuai dengan Gambar 2. Bobot digunakan dalam formulasi matematis untuk mendapatkan skor akhir. Dalam kasus WS Bengawan Solo, bobot masing-masing variabel adalah: geologi (40\%), jenis lapis tanah permukaan (30\%), curah hujan (20\%), dan kelerengan (10\%).

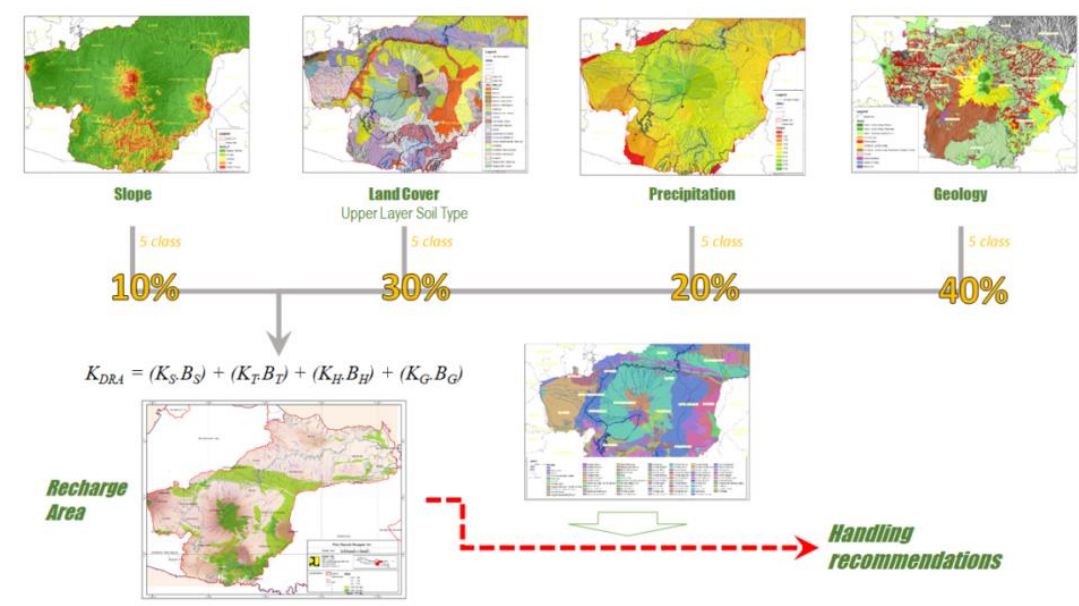

Gambar 2. Proses overlay antar variabel utama dan overlay area imbuhan dengan tata guna lahan untuk penanganan rekomendasi.

Proses overlay adalah proses menumpang-susunkan peta setiap variabel penentu DRA untuk menghasilkan peta DRA. Klasifikasi/rangking DRA didapatkan dari hasil penjumlahan perkalian antara bobot variabel (B) dengan klas variabel (K), dengan formulasi sebagai berikut:

$$
\mathrm{K}_{\text {DRA }}=\left(\mathrm{K}_{\mathrm{S}} \cdot \mathrm{B}_{\mathrm{S}}\right)+\left(\mathrm{K}_{\mathrm{T}} \cdot \mathrm{B}_{\mathrm{T}}\right)+\left(\mathrm{K}_{\mathrm{H}} \cdot \mathrm{B}_{\mathrm{H}}\right)+\left(\mathrm{K}_{\mathrm{G}} \cdot \mathrm{B}_{\mathrm{G}}\right)
$$


Dengan:

$K_{S} \quad$ : Nilai Klas/Rangking variabel slope

$K_{T} \quad$ : Nilai Klas/Rangking variabel jenis tanah

$K_{H}$ : Nilai Klas/Rangking variabel curah hujan

$K_{G}$ : Nilai Klas/Rangking variabel kondisi geologi

$B$ : Bobot pengaruh variabel

\section{HASIL DAN PEMBAHASAN}

4.1 Hasil klasifikasi akhir DRA

Rentang nilai klas pada hasil overlay DRA selanjutnya dibagi menjadi 5 klas dengan interval yang sama. 2 interval tertinggi selanjutnya disebut dengan DRA Prioritas I dan Prioritas II, dengan asumsi bahwa daerah ini yang akan ditetapkan menjadi DRA. DRA Prioritas I adalah merupakan daerah imbuhan utama, dan DRA Prioritas II adalah sebagai daerah imbuhan tambahan.

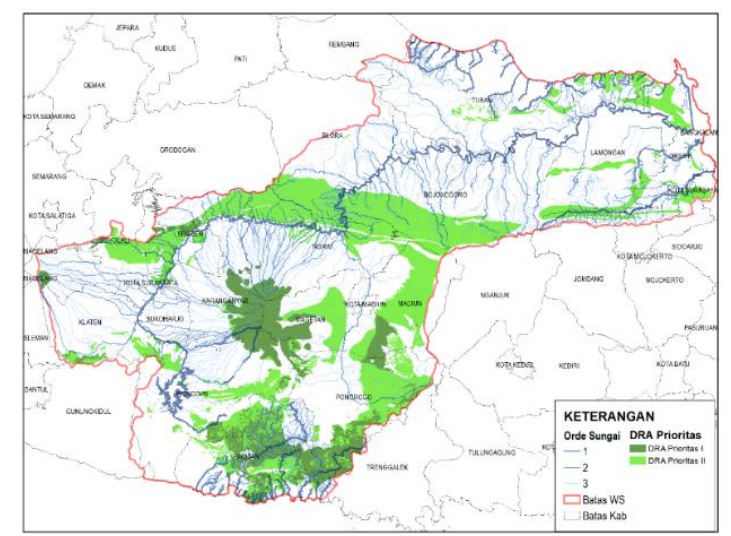

Gambar 3. Daerah Resapan Air prioritas

Peta hasil overlay DRA, selanjutnya diidentifikan/dioverlaykan kembali dengan batas administrasi untuk mengetahui luas DRA prioritas pada masing-masing kabupaten/kota. Hasil analisis luas DRA diperlihatkan dalam urutan kabupaten/kota mulai paling luas DRAnya sampai paling kecil adalah seperti terlihat di Tabel 2.

Tabel 2. Luas DRA prioritas I dan prioritas II berdasarkan kabupaten/kota

\begin{tabular}{lrrr}
\hline \multirow{2}{*}{ Kabupaten } & \multicolumn{2}{c}{ Luas DRA (Ha) } & \multicolumn{2}{c}{ Total Luas DRA (Ha) } \\
\cline { 2 - 4 } Blora & \multicolumn{1}{c}{ Prioritas I } & \multicolumn{1}{c}{ Prioritas II } & $26,128.25$ \\
\hline Bojonegoro & 18.28 & $70,099.86$ & $70,188.97$ \\
\hline Boyolali & 89.10 & $9,485.03$ & $11,834.56$ \\
\hline Gresik & $2,349.53$ & $20,275.41$ & $20,275.41$ \\
\hline Grobogan & 111.94 & 790.33 & 902.28 \\
\hline Gunung Kidul & 612.47 & $3,070.66$ & $3,683.14$ \\
\hline Jombang & & 54.62 & 54.62 \\
\hline Karanganyar & $19,919.71$ & $25,139.94$ \\
\hline Klaten & 369.83 & $5,220.23$ & $1,848.92$ \\
\hline Lamongan & & $1,479.09$ & $21,230.34$ \\
\hline Madiun & $8,355.09$ & $21,230.34$ & $49,341.11$ \\
\hline Magetan & $18,065.79$ & $40,986.02$ & $30,783.54$ \\
\hline Mojokerto & & $12,717.75$ & $1,538.41$ \\
\hline Nganjuk & & $1,538.41$ & 8.82 \\
\hline Ngawi & $6,574.62$ & 8.82 & $47,003.59$ \\
\hline Pacitan & $41,390.24$ & $40,428.97$ & $71,796.91$ \\
\hline Ponorogo & $22,415.58$ & $30,406.67$ & $65,844.99$ \\
\hline Rembang & 12.33 & $43,429.41$ & 47.77 \\
\hline Semarang & 37.87 & 35.44 & 48.00 \\
\hline Sleman & 18.70 & 10.13 & 259.07 \\
\hline Sragen & $4,825.51$ & 240.37 & $27,122.94$ \\
\hline Sukoharjo & 115.31 & $22,297.43$ & $4,534.88$ \\
\hline & & $4,419.57$ & \\
\hline
\end{tabular}




\begin{tabular}{|c|c|c|c|}
\hline \multirow{2}{*}{ Kabupaten } & \multicolumn{2}{|c|}{ Luas DRA (Ha) } & \multirow{2}{*}{ Total Luas DRA (Ha) } \\
\hline & Prioritas I & Prioritas II & \\
\hline Surabaya & & $1,648.38$ & $1,648.38$ \\
\hline Surakarta & & 654.52 & 654.52 \\
\hline Trenggalek & $1,498.87$ & 623.01 & $2,121.88$ \\
\hline Tuban & 17.83 & $4,020.43$ & $4,038.26$ \\
\hline Wonogiri & $18,607.11$ & $25,788.43$ & $44,395.54$ \\
\hline Total & $145,405.72$ & $387,069.29$ & $532,475.01$ \\
\hline
\end{tabular}

Hasil identifikasi DRA, terdapat 532.475,01 hektar yang dapat digunakan sebagai DRA di Wilayah Sungai Bengawan Solo, terdiri dari 387.069,29 Hektar Prioritas II dan 145.405,72 Prioritas I. Luas total DRA sekitar 29,7\% dari luar wilayah sungai. Dalam bentuk grafik, proporsi luas DRA tiap kabupaten/kota diperlihatkan dalam Gambar 4.

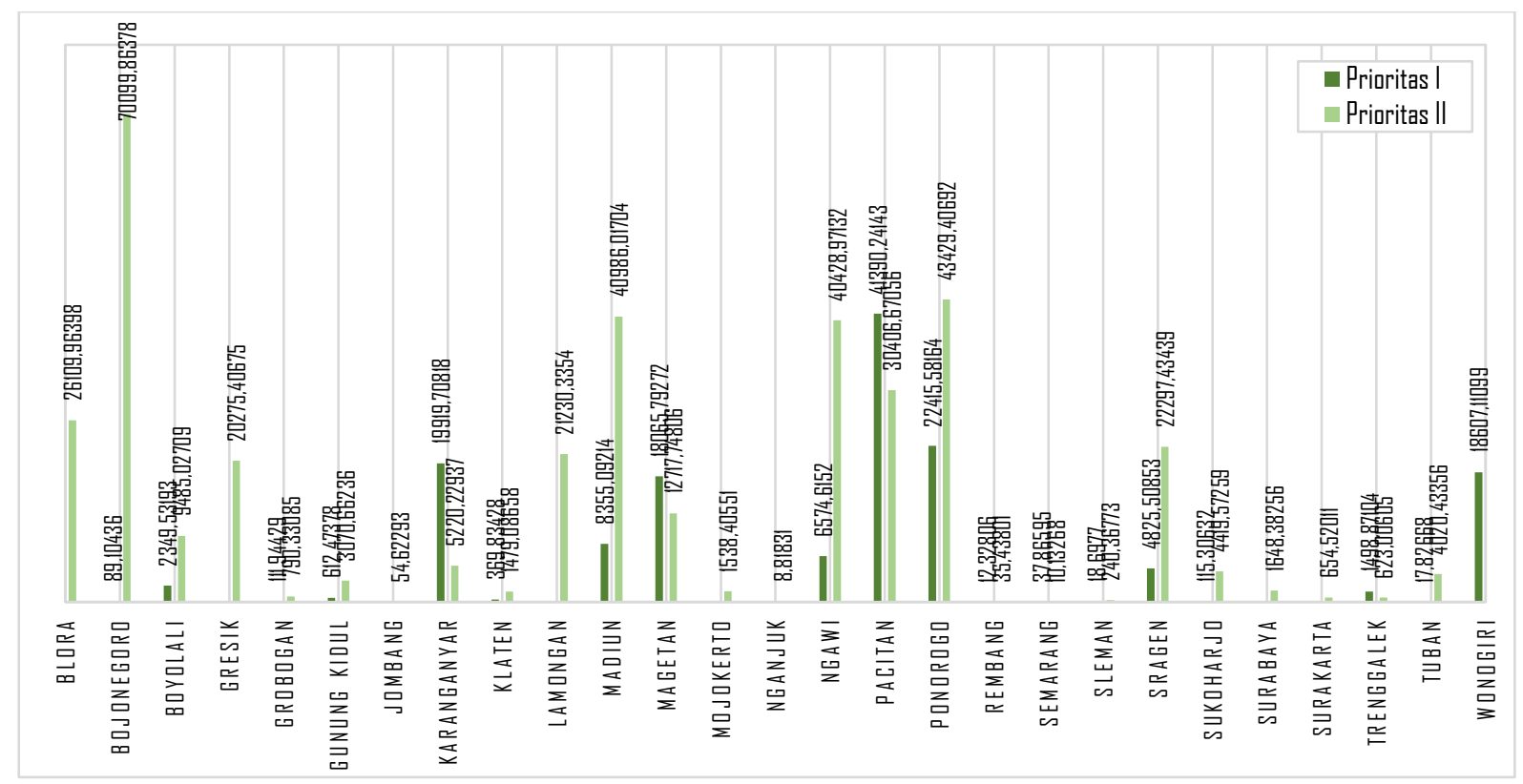

Gambar 4. Luas daerah resapan air (DRA) pada masing-masing kabupaten/kota berdasarkan prioritasnya

Dalam bentuk 3D, DRA hasil identifikasi dapat dilihat pada Gambar 5 dan terlihat bahwa karakteristik DRA antara lain adalah berada di daerah pegunungan (seperti di Kabupaten Wonogiri dan Karanganyar) atau punggung-punggung bukit (seperti di Kabupaten Pacitan).

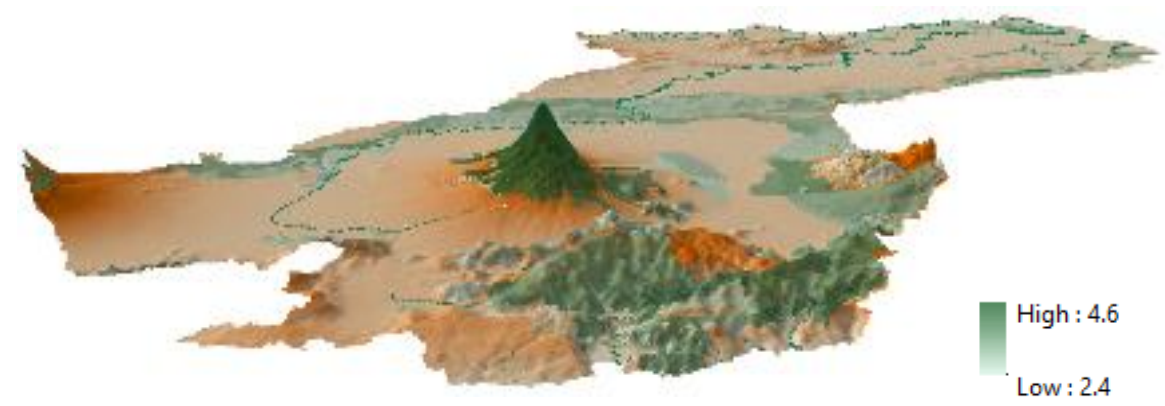

Gambar 5. Hasil plotting DRA dalam Digital Elevation Model (DEM)

\subsection{Hasil validasi DRA}

Validasi hasil penentuan DRA dilakukan dengan meninjau langsung ke lapangan di beberapa titik untuk melihat kondisi wilayah dan memastikan apakah benar daerah tersebut merupakan DRA. Tinjauan ke lapangan dilakukan di 3 titik berbeda yaitu di Kabupaten Pacitan, Wonogiri, dan Karanganyar. Validasi juga menggunakan peralatan drone (pesawat tanpa awak), untuk mengambil foto dari ketinggian tertentu. Hasil foto kemudian digunakan untuk melihat batas antar daerah resapan dan non-resapan apakah sesuai dengan hasil analisis yang sudah dilakukan. 


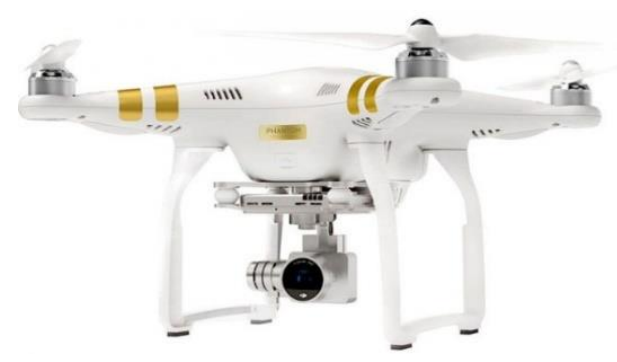

Gambar 6. Drone Phantom Advanced yang digunakan validasi lapangan

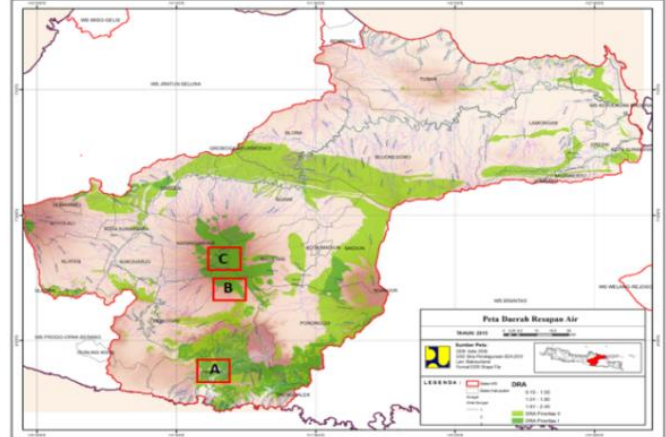

Gambar 7. Tiga lokasi validasi

Hasil validasi di Kabupaten Pacitan menunjukkan bahwa batas antara DRA dan non DRA hasil analisis memiliki kemiripan yang baik. DRA ditunjukkan dengan tingkat vegetasi yang tinggi dan berada dilereng-lereng bukit. Gambar 8 menunjukkan batas DRA hasil analisis dan batas yang ada di alam di sampel wilayah Kabupaten Pacitan. Sedangkan Gambar 9 menunjukkan batas DRA hasil analisis dan batas yang ada di alam di sampel wilayah Kabupaten Wonogiri.

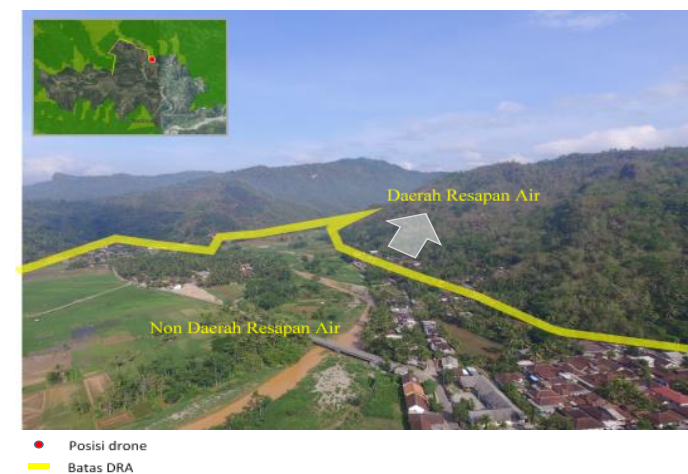

Gambar 8. Hasil validasi lapangan (titik A) DRA di Kabupaten Pacitan Arah Barat

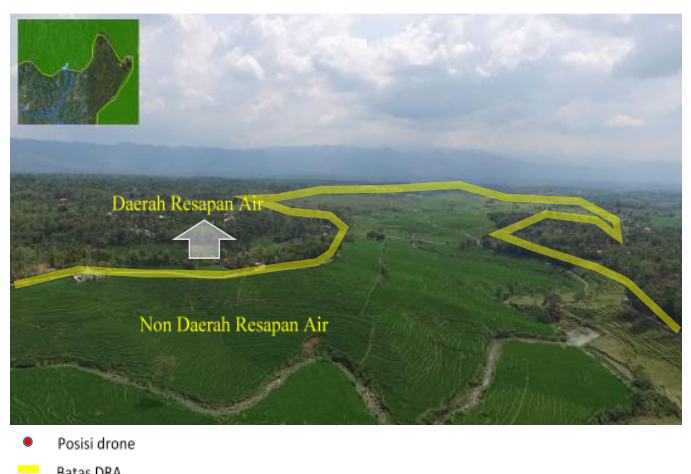

Gambar 9. Hasil validasi lapangan (titik B) DRA di Kabupaten Wonogiri Arah Selatan

\section{KESIMPULAN}

Rentang kelas masing-masing variabel bisa berbeda-beda tergantung kondisi wilayah kajian;

Hasil identifikasi DRA, terdapat 532.475,01 hektar yang dapat digunakan sebagai DRA di Wilayah Sungai Bengawan Solo, terdiri dari 387.069,29 Hektar Prioritas II dan 145.405,72 Prioritas I. Luas total DRA sekitar 29,7\% dari luar wilayah sungai.

Dari hasil identifikasi DRA, dapat disimpulkan bahwa lahan yang merupakan DRA mempunyai ciri-ciri utama seperti:

- Aliran air tanah umumnya mempunyai arah vertikal ke bawah dilihat dari struktur geologinya.

- Air merembes masuk ke dalam tanah (mengisi akuifer) mencapai elevasi air tanah.

- Daerahnya terdiri dari batuan singkapan yang lolos air namun tak jenuh air.

- Daerahnya terdiri dari bukit atau pegunungan

- Air tanahnya berumur relatif muda.

- Daerahnya berupa tubuh serta puncak kerucut dari gunung api.

- Terdapat area karst dengan retakan serta lubang pelarutan.

- Terdapat beberapa kawasan permukiman yang berada di DRA.

\section{UCAPAN TERIMA KASIH}

Ucapan terima kasih disampaikan kepada Dr. Nindyo Cahyo Kresnanto, S.T., M.T., atas saran dan arahannya dalam penerapan Sistem Informasi Geografis.

\section{DAFTAR PUSTAKA}

[1] R. J. Kodoatie and R. Sjarief, Pengelolaan Sumber Daya Air Terpadu (Edisi 2). Yogyakarta: Andi Offset, 2008.

[2] J. R. Nimmo, R. W. Healy, and D. A. Stonestrom, “Aquifer Recharge,” Encycl. Hydrol. Sci., pp. 2229-2246, 2005, doi: 10.1002/0470848944.hsa161a.

[3] Lake Simcoe Region Conservation Authority, Guidance for the protection and restoration of significant groundwater recharge areas (SGRAs) in the Lake Simcoe watershed. 2014.

[4] I. Touhami, E. Chirino, and H. Moutahir, "Estimation of aquifer recharge and its importance for a sustainable groundwater management in a semi-arid Mediterranean region ( Ventós ," no. October, 2014.

[5] G. H. Karami, R. Bagheri, and F. Rahimi, "Determining the groundwater potential recharge zone and karst springs 
catchment area: Saldoran region, western Iran,” Hydrogeol. J., vol. 24, no. 8, pp. 1981-1992, 2016, doi: https://doi.org/10.1007/s10040-016-1458-z.

[6] G. W. P. GWP, The links between land use and groundwater. 2014.

[7] S. G. Patil and N. M. Mohite, "Identification of groundwater recharge potential zones for a watershed using remote sensing and GIS," Int. J. Geomatics Geosci., vol. 4, no. 3, pp. 485-498, 2014.

[8] S. Kaliraj, N. Chandrasekar, and N. S. Magesh, "Identification of potential groundwater recharge zones in Vaigai upper basin, Tamil Nadu, using GIS-based analytical hierarchical process (AHP) technique," Arab. J. Geosci., vol. 7, no. 4, pp. 1385-1401, 2014, doi: 10.1007/s12517-013-0849-x.

[9] N. Hammouri, H. Al-Amoush, M. Al-Raggad, and S. Harahsheh, "Groundwater recharge zones mapping using GIS: A case study in Southern part of Jordan Valley, Jordan,” Arab. J. Geosci., vol. 7, no. 7, pp. 2815-2829, 2014, doi: 10.1007/s12517-013-0995-1.

[10] R. Palaka and G. J. Sankar, "Identification of Potential Zones for Groundwater Recharge in Kosigi Mandal , Kurnool District , using Remote Sensing and GIS," Int. J. Curr. Eng. Technol., vol. 5, no. 1, pp. 12-19, 2015.

[11] N. C. Kresnanto and E. Sriyono, "Identification of recharge area in Bengawan Solo Indonesia catchment areas based on Geographic Information System Identification of recharge area in B engawan S olo Indonesia catchment areas based on G eographic I nformation S ystem," 2019, doi: 10.1088/1757-899X/508/1/012040.

[12] S. Kusumadewi, S. Hartati, and A. Harjoko, Fuzzy Multi Attribute Decision Making (Fuzzy MADM). Yogyakarta: Graha Ilmu, 2006.

[13] C. Kahraman, Fuzzy Multi-Criteria Decision Making. Istanbul, Turkey: Springer, 2008.

[14] E. Kornyshova and C. Salinesi, "MCDM techniques selection approaches: State of the art," Proc. 2007 IEEE Symp. Comput. Intell. Multicriteria Decis. Making, MCDM 2007, no. Mcdm, pp. 22-29, 2007, doi: 10.1109/MCDM.2007.369412.

[15] A. Toloie-eshlaghy, "MCDM Methodologies and Applications : A Literature Review from 1999 to 2009 ," Res. J. International Studies, vol. 21, no. 21, pp. 86-137, 2011.

[16] G. Kabir, R. Sadiq, and S. Tesfamariam, "A review of multi-criteria decision-making methods for infrastructure management," Struct. Infrastruct. Eng., vol. 10, no. 9, pp. 1176-1210, 2014, doi: 10.1080/15732479.2013.795978.

[17] A. Mardani, A. Jusoh, K. M. D. Nor, Z. Khalifah, N. Zakwan, and A. Valipour, "Multiple criteria decision-making techniques and their applications - A review of the literature from 2000 to 2014," Econ. Res. Istraz., vol. 28, no. 1, pp. 516-571, 2015, doi: 10.1080/1331677X.2015.1075139.

[18] M. M. De Brito and M. Evers, "Multi-criteria decision-making for flood risk management: A survey of the current state of the art," Nat. Hazards Earth Syst. Sci., vol. 16, no. 4, pp. 1019-1033, 2016, doi: 10.5194/nhess-16-1019-2016.

[19] A. Ishizaka and A. Labib, "Review of the main developments in the analytic hierarchy process," vol. 38, no. 11, pp. 14336-14345, 2011, doi: 10.1016/j.eswa.2011.04.143.

[20] M. Velasquez and P. T. Hester, “An Analysis of Multi-Criteria Decision Making Methods,” Int. J. Oper. Res., vol. 10, no. 2, pp. 56-66, 2013, doi: 10.1007/978-3-319-12586-2.

[21] O. Andreichicova and A. Andreichicov, “About Some Features of Ahp / Anp Applications,” 2013.

[22] a Görener, "Comparing AHP and ANP: An Application of Strategic Decisions Making in a Manufacturing Company," Int. J. Bus. Soc. Sci., vol. 3, no. 11, pp. 194-208, 2012.

[23] T. L. Saaty, "Decision making with the analytic hierarchy process," Int. J. Serv. Sci., vol. 1, no. 1, p. 83, 2008, doi: 10.1504/IJSSCI.2008.017590.

[24] T. L. Saaty, "How to make a decision: The Analytic Hierarchy Process," European Journal of Operational Research, vol. 48. pp. 9-26, 1990, doi: 10.1016/0377-2217(90)90057-I.

[25] H. Tanjung and H. Devi, Metode Penelitian Ekonomi Islam. Jakarta: Gramata Publishing, 2013.

[26] T. L. Saaty, Theory and Applications of the Analytic Network Process. Pittsburgh: PA: RWS Publications, 2005.

[27] I. J. Azis, “Analytic Network Process With Feedback Influence : A New Approach to Impact Study * Methodology: From Hierarchy to Network," pp. 1-22, 2003. 